\title{
適応制御による超音波モータの速度制御
}

$\begin{array}{llllll}\text { 正員 } & \text { 住 } & \text { 智 } & \text { 信 } & \text { (琉球大) } \\ \text { 非会員 } & \text { 平 } & \text { 良 } & & \text { 淳 } & \text { (琉球大) } \\ \text { 正員 上 } & \text { 里 } & \text { 勝 } & \text { 実 } & \text { (琉球大) }\end{array}$

\section{Speed Control of Ultrasonic Motor by Adaptive Control}

Tomonobu Senjyu, Member, Jun Taira, Non-member, Katsumi Uezato, Member (University of the Ryukyus)

キーワード：超音波モータ, 適応制御, STC, 速度制御, 特性変動

\section{1. まえがき}

超音波モー夕 (Ultrasonic Motor; USM) は，小 形で軽量, 低速, 高トルク，磁気作用がないなど, 従 来の電磁モータにはない優れた性能と特徽を備えてお り，小形モータの利用分野における応用が期待されて いる。このモー夕は, 固定子の機械系共振周波数近傍 で回転する特殊モータであり, 温度上昇による特性変 動のため, 駆動周波数が一定でも一定の回転速度を得 ることができない(1)。本レタ一は，温度上犁によるモ 一タの特性変動に対しても，常に一定の回転速度を得 るために，適応制御を適用した制御法を提案する。

\section{2. 適応制御による速度制御}

超音波モー夕は摩擦駆動力により回転する特殊モー 夕であり，その動特性モデルはまだ確立されていな い。そこで,プラントの動特性が末知の場合の制御法 として知られている適応制御により，モータの速度制 御を行う。本レターでは，適㖃制御の一手法である STC (Self-Tuning Controller) により制御系を構築 する。

図 1 k, モー夕駆動周波数 $f$ に対する回転速度特 性を示す。同図は運転前の特性 $(a)$ と 2 分間運転後の 特性 (b) を示している。同図からわかるように，モー 夕の特酷は短時間で大きく変化する。また，周波数対 回転速度特性は非線形である。従って, 直接周波数 $f$ によって制街することは困難なため，ある基準となる 周波数 $f^{*}$ からの変化分 $\Delta f$ により制御する。

STCによる速度制御システムの構成図を図 2 に示 す。ここで, $y(k)$ は回転速度 $(\mathrm{rpm}), y_{m}(k)$ は指令速 度， $u(k)$ 倒御入力て $\Delta f(\mathrm{kHz})$ である。また，

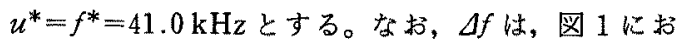

いて $f$ を隇少させる方向を正とする。

ここで, STCの刘象とするモデルは(1)式で表せ るものとして, コントローラおよび同定器の設計を行 5

$$
\begin{aligned}
A y(k)= & q^{-d} B u(k)+w(k) \cdots \cdots \cdots \cdots \\
& \left\{\begin{array}{l}
A=1+a_{1} q^{-1}+\cdots+a_{n} q^{-n} \\
B=b_{0}+b_{1} q^{-1}+\cdots+b_{m} q^{-m}
\end{array}\right.
\end{aligned}
$$

ただし， $w(k)$ は白色雑音， $d(d \geq 1)$ は蛙だ間を表 \$。

コントローラは, 制御入力の制限を考慮した( 2 )式

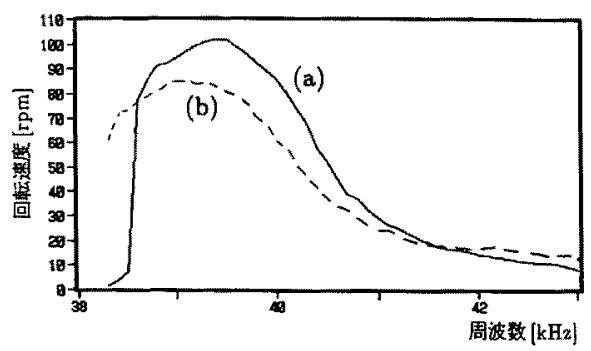

図 1 勡動周波数 $f$ 対回転速度特性

Fig. 1. Rotation speed vs. drive frequency.

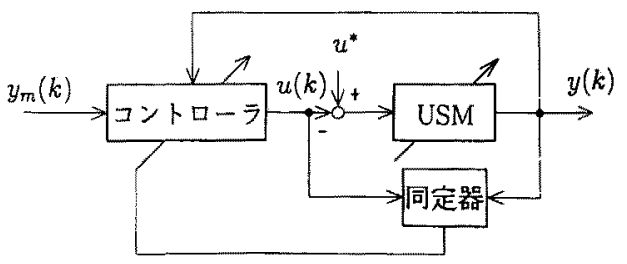

図 2 STCによる速度制御システム

Fig. 2, Speed control system.

T. IEE Japan, Vol. 113-D, No. 10,'93 


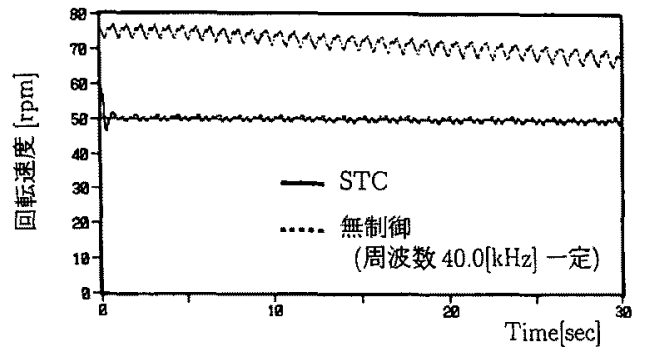

図 3 STCによる速度制御

Fig. 3. Speed control by STC.

の評価関数 $J$ を最小とする $u(k)$ を構成するように設 計する。

$$
\begin{aligned}
J= & E\left[\left\{y(k+d)-y_{m}(k+d)\right\}^{2}\right. \\
& \left.+\lambda\{u(k)-u(k-1)\}^{2}\right] \cdots
\end{aligned}
$$

ただし，E[・]は期待值作用を表しており， $\lambda$ は重み 係数である。

$J$ を最小とする $u(k)$ の関係式は, $\partial J / \partial u(k)=0$ と おくことにより，

$$
\begin{aligned}
& \left\{B R+\frac{\lambda}{b_{0}}\right\} u(k) \\
& \quad=y_{m}(k+d)-H y(k)+\frac{\lambda}{b_{0}} u(k-1)
\end{aligned}
$$

となる(2)。ただし， $R, H$ は ( 4 )式の恒等式より一意 に決定される。

$$
\begin{aligned}
1= & A R+q^{-d} H \cdots \cdots \cdots \\
& \left\{\begin{array}{l}
R=1+r_{1} q^{-1}+\cdots+r_{d-1} q^{-(d-1)} \\
H=h_{0}+h_{1} q^{-1}+\cdots+h_{n-1} q^{-(n-1)}
\end{array}\right.
\end{aligned}
$$

同定器は，逐次繰返し最小二乗法のアルゴリズムを 用いて(1)式のパラメー夕を同定する。なお, 多項式 の次数 $n, m$ およびむだ時間 $d$ は, 良好な制御結果が 得られる值を用いる。

\section{3. 実験結果と検討}

実験は周波数 $40.2 \mathrm{kHz}$ 一定でモータを 2 秒間回転 させた後，時刻 $t=0 \mathrm{~s}$ 加ら制御と同定を同時に開始 した。制御周期は $40 \mathrm{~ms}$ とし，また $u(k)$ は $0 \leq u(k)$ $\leq 1 \mathrm{kHz}$ の範囲内に制限した。

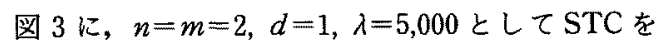
設計した場合の回転速度の制御結果を示す。ただし, $y_{m}(k)=50 \mathrm{rpm}$ 一定である。また,このときのパラメ 一夕の同定過程を図 4 , 図 5 k示す。

図3より明らかなように，無制御の場合 (破線)， 駆動周波数が一定であるにもかかわらず，回転速度は 大きく脈動し, 更に温度変化に伴う特性変動により, 平均回転速度が低下している。STCで制御した場合

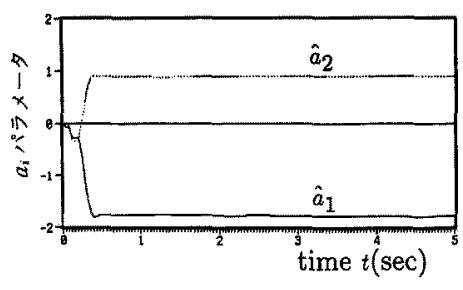

図 $4 a_{i}$ パラメー夕の同定過程

Fig. 4. Identification of parameter $a_{i}$.

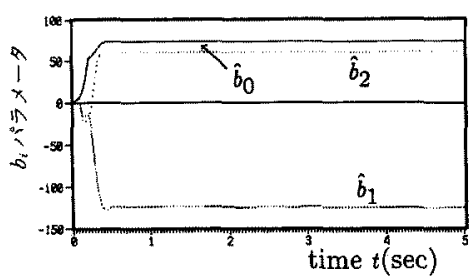

図 $5 b_{i}$ パラメータの同定過程

Fig. 5. Identification of parameter $b_{i}$.

は, 回転速度に多少の脈動が生じているが, 指令速度 にほほ一致していることがわかる。また，図 4 , 図 5 よりシステムパラメータ $\left(a_{i}, b_{i}\right)$ も短時間で同定でき ることがわかる。システムに同定器がなければ, パラ メータがオンラインで同定できないため, モータの良 好な速度制御は困難である。

\section{4.むすび}

超音波モー夕の速度制御法として適応制御を適用す る手法を提案し，実験により本手法の有効性を確認し た。また, 超音波モータのモデル式を差分方程式で表 現する方法を提案した。 (平成 5 年 3 月 19 日受付)

$$
\text { 文献 }
$$

（1）泉野・中凧：「進全波形超音波モ一夕駆動系の適応制御技法 による高性能化」, 電学論 D, 110, 1147 (平 2-11)

(2) D.W. Clarke: "Self-Tuning Control of Nonminimumphase Systems", Automatica, 20, No. 5, 501 (1984)

千 住智信 (正員)

(電学諭 D, Vol. 113, No. 6, p. 800 参照)

平 良淳 (非会員) (写真省略)

昭和 45 年 11 月 22 日生。平成 5 年 3 月琉球大学工学 部電子・情報工学科卒業。同年 4 月沖縄県庁入庁。在学 中は，超音波モー夕の速度制御法に関する研究に従事。

\section{上里勝実 (正員)}

(電学論 D, Vol. 113, No. 6, p. 800 参照) 